\title{
KEMAMPUAN BERPIKIR KREATIF SISWA KELAS VIII PADA MATERI KUBUS DAN BALOK MELALUI STRATEGI PEMBELAJARAN TIME TOKEN STUDENT FACILITATOR AND EXPLAINING
}

\author{
Jamilatul Awwalin ${ }^{1}$ \\ ${ }^{1}$ Guru Matematika MTs. Al-Ittihad Belung Poncokusumo Malang \\ Email: ${ }^{1}$ milamuisin@gmail.com
}

\begin{abstract}
Abstrak
Penelitian ini bertujuan untuk meningkatkan berpikir kreatif siswa kelas VIII MTs. AlIttihad Belung Poncokusumo Malang. Pada materi kubus dan balok melalui strategi pembelajaran time token student facilitator and explaining. Pada penelitian ini pendekatan yang digunakan adalah pendekatan kualitatif dengan jenis penelitian tidakan kelas partisipan. Subjek dalam penelitian adalah siswa kelas VIII-i MTs. Al-Itiihad Belung Poncokusumo Malang. Teknik pengumpulan data yang dilakukan terdiri dari (1) tes, (2) observasi, dan (3) catatan lapangan. Data yang diperoleh dalam penelitian ini ada dua jenis yaitu data kualitatif dan data kuantitatif sebagai pelengkap dari data kualitatif. Data kualitatif dianalisis dengan tiga tahap yaitu: reduksi data, penyajian data dan verifikasi data. Sedangkan data kuantitatif dianalisis secara deskriptif, yaitu dengan mencari presentase ketuntasan belajar siswa. Berdasarkan hasil penelitian menunjukan bahwa strategi pembelajaran time token student facilitator and explaining dapat meningkatkan kemampuan berpikir kreatif siswa kelas VIII-i MTs. Al-Ittihad Belung Poncokusumo Malang tahun ajaran 2016/2017. Hasil peningkatan kemampuan berpikir kreatif siswa tersebut adalah sebagai berikut (1) ketuntasan belajar siswa meningkat $57,14 \%$ dari siklus I ke siklus II, (2) keterlaksanaan pembelajaran meningkat 10,25\% dari siklus I ke siklus II, dan (3) kegiatan pembelajaran siswa meningkat $17,26 \%$ dari siklus I ke siklus II. Berdasarkan hasil tersebut di atas dapat disimpulkan bahwa strategi pembelajaran time token student facilitator and explaining dapat meningkatkan kemampuan berpikir kreatif siswa kelas VIII-i MTs. Al-Ittihad Belung Poncokusumo Malang tahun ajaran 2016/2017.
\end{abstract}

Kata Kunci: kemampuan berpikir kreatif, strategi pembelajaran time token student facilitator and explaining

\section{PENDAHULUAN}

Matematika sering dianggap sebagai mata pelajaran yang sulit dan membosankan bagi siswa, sehingga tidak sedikit dari siswa merasa malas ketika akan mengikuti pelajaran matematika. Matematika seakan menjadi sesuatu yang ditakuti oleh siswa, sehingga tak jarang siswa masih memperoleh nilai yang rendah. Begitu pula yang diungkapkan oleh Sundayana (2015:2) bahwa sampai saat ini masih banyak siswa yang menganggap matematika sebagai mata pelajaran yang sulit, tidak menyenangkan, bahkan momok yang menakutkan.

Sundayana (2015:2) berpendapat bahwa, sampai saat ini masih banyak siswa yang menganggap matematika sebagai mata pelajaran yang sulit, tidak menyenangkan, bahkan momok yang menakutkan. Dengan kata lain, Mempelajari hal yang bersifat abstrak adalah suatu hal sulit, inilah yang menjadi salah satu faktor peserta didik memandang bahwa matematika adalah sesuatu yang menakutkan. Suatu hal yang menakutkan bagi siswa akan mengakibatkan kemalasan dalam menerima materi pembelajaran dan membosankan berada di 
ruang kelas. Hal tersebut akan memungkinkan berpengaruh terhadap pola berpikir siswa, salah satunya adalah pola berpikir kreatif siswa.

Berdasarkan hasil wawancara terhadap guru matematika kelas VIII-i MTs. Al-Ittihad Belung Poncokusumo Malang menyatakan bahwa, siswa yang ada di kelas tersebut berpikir kreatifnya rendah, hal ini berdasar pada kegagalan tes berpikir kreatif yang dilakukan oleh guru tersebut. Hasil observasi di lapangan menunjukan bahwa proses pembelajaran yang terjadi di kelas VIII-i dapat menghambat peningkatan pola berpikir kreatif siswa, seperti siswa diposisikan hanya sebagai pendengar ceramah guru dalam proses pembelajaran. Sehingga proses belajar mengajar cenderung membosankan dan menjadikan siswa malas belajar, siswa didoktrin untuk mengikuti cara penyelesaian yang disampaikan oleh saja.

Berpikir kreatif yang dimaksud adalah siswa mampu untuk menciptakan ide-ide atau gagasan yang baru. Torrance (dalam Filsaime, 2008:20) melihat berpikir kreatif sebagai sebuah proses yang meliputi unsur-unsur orisinalitas, kelancaran, fleksibilitas dan elaborasi. Menurut Guilford (dalam Filsaime, 2008:21) karakteristik berpikir kreatif adalah. (1) orisinality (keaslian), kategori orisinalitas mengacu pada keunikan dari respon appun yang diberikan. Orisinalitas yang ditunjukan oleh sebuah respon diluar kebiasaan, unik, dan jarang terjadi; (2) Elaborasi (penguraian) adalah kemampuan untuk menguraikan sebuah obyek tertentu. Dan dapat pula menjadi sebuah jembatan yang harus dilalui oleh seseorang untuk mengkomunikasikan ide kreatifnya; (3) Fluency (kelancaran) adalah lemampuan untuk mencetuskan banyak ide. Semakin banyak ide yang

tercipta maka semakin besar kemungkinan untuk memperoleh sebuah ide yang signifikan; dan (4) Flexibility (keluwesan), karakteristik ini menggambarkan kemampuan untuk mengemukakan bermacam-macam pemecahan atau pendekatan terhadap masalah.

Meningkatkan kemampuan berpikir kreatif siswa tidaklah mudah. Menurut Pearce (dalam Filsaime, 2008:27), untuk bisa berpikir kreatif, manusia harus menghilangkan ketakutan akan salah. Sedangkan dalam kegiatan pembelajaran kelas VIII-i MTs. Al-Ittihad Belung Poncokusumo Malang sering dijumpai beberapa masalah antara lain: (1) hampir tidak ada siswa yang mempunyai inisiatif untuk bertanya pada guru, (2) sibuk menyalin apa yang ditulis dan diucapkan guru, (3) apabila ditanya guru tidak ada yang mau menjawab tetapi mereka menjawab secara bersamaan sehingga suara kurang jelas, (4) apabila dipersilahkan maju untuk menjawab soal siswa takut salah dalam menjawab soal, (5) siswa terkadang ribut sendiri waktu guru menerangkan materi di depan kelas.

Berbagai usaha telah dilakukan guru matematika dalam mengatasi permasalahan tersebut, seperti melakukan diskusi dan tanya jawab dalam kelas. Namun usaha tersebut belum mampu merangsang peserta didik untuk aktif dalam pembelajaran, karena peserta didik yang menjawab pertanyaan guru, cenderung beberapa peserta didik saja. Sedangkan peserta didik yang lain hanya mendengarkan dan mencatat informasi yang disampaikan oleh temannya. Usaha lain yang dilakukan guru adalah dengan mengadakan diskusi dalam kelompok kecil. Akan tetapi peserta didik lebih banyak bekerja sendiri-sendiri dalam menyelesaikan soal yang diberikan oleh guru, kurang adanya diskusi antar peserta didik.

Dari permasalahan tersebut di atas, hendaknya guru matematika harus mampu memilih dan menerapkan strategi pembelajaran yang mampu merangsang siswa untuk lebih aktif dalam belajar matematika dan meningkatkan kemampuan berpikir kreatif siswa dalam belajar matematika. Menurut Darmansyah (2010:17) strategi pembelajaran merupakan cara pengorganisasian isi pelajaran, penyampaian pelajaran dan pengelolaan kegiatan belajar dengan menggunakan berbagai sumber belajar yang dapat dilakukan guru untuk mendukung terciptanya efektivitas dan efisiensi proses pembelajaran. Sehingga dalam belajar matematika tidak hanya mendengarkan guru di depan kelas saja, tetapi memerlukan banyak latihan- 
latihan, berani mengemukakan ide dan berani bertanya, berani mengerjakan soal-soal di depan kelas.

Salah satu langkah yang dapat dilakukan untuk mengatasi permasalahan di atas adalah dengan mencoba menerapkan strategi pembelajaran time token student facilitator and explaining, strategi pembelajaran time token student facilitator and explaining merupakan modifikasi dua strategi pembelajaran yaitu strategi pembelajaran time token dan strategi pembelajaran student facilitator and explaining. Tujuan dari strategi pembelajaran time token student facilitator and explaining adalah siswa yang akan menjadi fasilitator pada temantemannya dengan menjelaskan suatu bahan materi yang telah disampaikan oleh guru. Untuk menghindari siswa mendominasi pembicaraan atau siswa diam sama sekali maka dimanfaatkan sebuah kupon berbicara. Sehingga dalam belajar matematika siswa tidak hanya mendengarkan ceramah guru di depan kelas saja, tetapi memerlukan banyak latihan-latihan, berani mengemukakan ide, berani bertanya, berani mengerjakan soal-soal di depan kelas dan diharapkan pembelajaran di dalam kelas bisa menyenangkan.

Berdasarkan uraian di atas, diperlukan penelitian tentang penerapan strategi pembelajaran time token student facilitator and explaining untuk meningkatkan kemampuan bepikir kreatif siswa pada pokok bahasan kubus dan balok kelas VIII MTs. Al- Ittihad Belung Poncokusumo Malang tahun ajaran 2016/2017. Hasil penelitian ini diharapkan dapat bermanfaat bagi guru maupun siswa sebagai suatu usaha dalam menigkatkan kemampuan berpikir siswa pada pembelajaran matematika.

\section{METODE}

Pada penelitian ini pendekatan yang digunakan adalah pendekatan kualitatif. Bogdan dan Taylor (dalam Moleong, 2013:4) mendefinisikan metodologi kualitatif sebagai prosedur penelitian yang menghasilkan data deskriptif berupa kata-kata tertulis atau lisan dari orangorang dan perilaku yang dapat diamati. Menurut Moleong (2013:6) penelitian kualitatif adalah penelitian yang bermaksud untuk memahami fenomena tentang apa yang dialami oleh subjek penelitian secara holistik. Hasil dari penelitian akan dideskripsikan dalam bentuk kata-kata dan bahasa, pada suatu konteks khusus yang alamiah dan dengan memanfaatkan berbagai metode alamiah. Fenomena yang dimaksud dalam penelitian ini adalah peristiwa yang terjadi secara alami terhadap aktivitas siswa di dalam kelas yang berkaitan dengan berpikir kreatif siswa dalam pokok bahasan kubus dan balok melalui strategi pembelajaran time token student facilitator and explaining.

Menurut Gall dan Borg (dalam Wiriaatmadja, 2012:4), salah satu bentuk penelitian yang menggunakan pendekatan kualitatif adalah penelitian emansipatoris tindakan (emancipatory action research). Dalam perkuliahan biasanya disebut dengan istilah Penelitian Tindakan Kelas (PTK) atau classroom action research. Sebagai pelengkap analisis data kualitatif, penelitian ini juga menggunakan pendekatan kuantitatif. Pendekatan kuantitatif sifatnya melengkapi pendekatan kualitatif yang merupakan pendekatan utama dalam penelitian ini. Penggabungan kedua pendekatan ini, dapat dilakukan jika salah satu diantaranya bersifat melengkapi pendekatan utama dari suatu penelitian. Adapun pendekatan kuantitatif yang digunakan mencakup statistik rata-rata dan persentase. Pendekatan kualitatif dalam penelitian ini digunakan untuk mengetahui gambaran secara jelas fenomena selama proses pembelajaran berlangsung melalui strategi pembelajaran time token student facilitator and explaining.

Teknik pengumpulan data yang dilakukan terdiri dari (1) tes, (2) observasi, dan (3) catatan lapangan. Tes digunakan untuk mengetahui kemampuan berpikir kreatif siswa, Observasi dilakukan untuk memperoleh data secara obyektif mengenai hal-hal yang terjadi selama pembelajaran berlangsung berupa aktivitas guru (peneliti) dan siswa. Catatan lapangan 
digunakan untuk melengkapi data yang tidak tercantum dalam lembar observasi sehingga tidak ada data yang terlewatkan.

Menurut Arikunto (2013:265), instrumen penelitian adalah alat bantu yang dipilih dan digunakan oleh peneliti dalam kegiatannya mengumpulkan data agar kegiatan tersebut menjadi sistematis dan dipermudah olehnya. Sebelum instrumen digunakan terlebih dahulu peneliti menguji validitas instrument tersebut. Pengujian ini dilakukan untuk mendapatkan instrumen yang valid. Validator instrument dalam penelitian ini yaitu dosen Pendidikan Matematika FKIP Unisma (Ibu Alifiani, M.Pd). Instrument yang digunakan dalam pengumpulan data terdiri dari (1) soal tes, (2) lembar observasi, dan (3) catatan lapangan. soal tes kemempuan berpikir kreatif terdiri dari 3 soal. Soal tes ini disusun berdasarkan indikator kemampuan berpikir kreatif yang telah diuraikan pada BAB II. Lembar observasi yang digunakan adalah lembar observasi terstruktur yang mengungkapkan aktivitas guru (peneliti) dan siswa selama proses pembelajaran menggunakan strategi pembelajaran time token student facilitator and explaining. Catatan lapangan digunakan untuk melengkapi data selama proses penelitian yang bersifat penting dan tidak tercantum pada lembar observasi. Dalam penelitian ini yang menjadi subjek penelitian adalah siswa kelas VIII-i MTs. Al-Ittihad Belung Poncokusumo Malang, yang terdiri dari 42 siswa. Materi yang dipilih adalah kubus dan balok.

Dalam penelitian ini data kualitatif dianalisis melalui 3 tahap kegiatan yang saling terkait sebagai berikut. (1) reduksi data, Sugiyono (2015:338) menyatakan bahwa mereduksi data merupakan merangkum, memilih hal-hal pokok, memfokuskan pada hal-hal yang penting, dicari tema dan polanya. Reduksi data dapat dilakukan antara lain dengan cara pemilihan, pemusatan perhatian dan sekaligus menyeleksi informasi-informasi yang relevan dengan penelitian; (2) penyajian data, dalam penelitian kualitatif data yang sudah direduksi, selanjutnya disajikan dalam bentuk narasi deskriptif (paparan data), sehingga peneliti akan lebih mudah menarik kesimpulan; dan (3) penarikan kesimpulan dan verifikasi, penarikan kesimpulan merupakan pemberian makna terhadap data yang direduksi dan dipaparkan sesuai dengan informasi yang diperlukan. Untuk mendapatkan kesimpulan yang akurat maka diperlukan pengujian atau verifikasi. Memverifikasi kesimpulan merupakan kegiatan menguji kebenaran, kecocokan tafsiran yang muncul dari paparan data yang ditampilkan.

\section{HASIL}

Pada penelitian ini terdiri dari dua siklus, pada siklus pertama terdiri dari tiga kali pertemuan, yaitu (1) pertemuan pertama pada hari Senin tanggal 5 Juni 2017 (pukul 06.4508.45) dilakukan pembelajaran I, (2) pertemuan kedua pada hari Rabu tanggal 7 Juni 2017 (pukul 08.05-10.05) dilakukan pembelajaran II, dan (3) pertemuan ketiga pada hari Kamis tanggal 8 Juni 2017 (pukul 11.55-12.35) diadakan tes akhir siklus I. pada siklus II juga terdiri dari tiga siklus yaitu: (1) pertemuan pertama pada hari Senin tanggal 12 Juni 2017 (pukul 06.45-08.45) dilakukan pembelajaran I, (2) pertemuan kedua pada hari Rabu tanggal 14 Juni 2017 (pukul 08.05-10.05) dilakukan pembelajaran II, dan (3) pertemuan ketiga pada hari Kamis tanggal 15 Juni 2017 (pukul 11.55-12.35) dilakukan tes akhir siklus II. Setelah melakukan penelitian, peneliti memperoleh data sebagai berikut. (1) observasi aktivitas guru pada Tabel 1, (2) observasi kegiatan siswa Tabel 2, (3) catatan lapangan , Dan (4) hasil tes ahir siklus table 4. Hasil catatan lapangan menunjukan dari pertemuan pertama pada siklus I sampai pertemuan 3 pada siklus II terjadi peningkatan mutu pembelajaran.

Tabel 1. Hasil Analisis Kegiatan Guru dengan Strategi Pembelajaran Time Token Student Facilitator and Explaining Siklus I dan Siklus II

\begin{tabular}{|c|c|c|c|}
\hline Siklus & Pertemuan & $\begin{array}{c}\text { Persentase } \\
\text { Keberhasilan } \\
\text { Tindakan }\end{array}$ & Taraf Keberhasilan \\
\hline
\end{tabular}




\begin{tabular}{clcc}
\hline \multirow{2}{*}{ I } & Pertama & $71 \%$ & Baik \\
\cline { 2 - 4 } & Kedua & $79,5 \%$ & Baik \\
\hline \multirow{2}{*}{ II } & Pertama & $81 \%$ & Sangat Baik \\
\cline { 2 - 4 } & Kedua & $90 \%$ & Sangat Baik \\
\hline
\end{tabular}

Tabel 2. Hasil Analisis Kegiatan Siswa dengan Time Token Student Facilitator and Explaining Siklus I dan Siklus II

\begin{tabular}{clcc}
\hline Siklus & Pertemuan & $\begin{array}{c}\text { Persentase Keberhasilan } \\
\text { Tindakan }\end{array}$ & Taraf Keberhasilan \\
\hline \multirow{2}{*}{ I } & Pertama & $62 \%$ & Baik \\
\cline { 2 - 4 } & Kedua & $66,5 \%$ & Baik \\
\hline \multirow{2}{*}{ II } & Pertama & $77,125 \%$ & Baik \\
\cline { 2 - 4 } & Kedua & $86,375 \%$ & Sangat Baik \\
\hline
\end{tabular}

Tabel 3. Hasil Tes Akhir Siklus I dan Siklus II

\begin{tabular}{ccccc}
\hline Siklus Ke- & Jumlah Siswa & $\begin{array}{c}\text { Jumlah Siswa } \\
\text { Tuntas }\end{array}$ & $\begin{array}{c}\text { Persentase } \\
\text { Ketuntasan }\end{array}$ & Keterangan \\
\hline I & 42 & 9 & $21,43 \%$ & Tidak Tuntas \\
\hline II & 42 & 33 & $78,57 \%$ & Tuntas \\
\hline
\end{tabular}

\section{PEMBAHASAN}

Berdasarkan Tabel 1 dapat dilihat bahwa kegiatan guru pada siklus I pertemuan pertama mencapai $71 \%$ dengan taraf keberhasilan baik dan pertemuan kedua mengalami peningkatan mencapai 79,5\% dengan taraf keberhasilan sangat baik. Persentase ini mencapai $75,25 \%$ belum memenuhi taraf keberhasil yang ditetapkan oleh peneliti yaitu $\geq 80 \%$, sehingga peneliti melanjutkan pada siklus berikutnya untuk melihat keajegan kegiatan guru dalam pembelajaran. Pada siklus II pertemuan pertama mengalami peningkatan mencapai $81 \%$ dengan taraf keberhasilan sangat baik dan pertemuan kedua mengalami peningkatan mencapai $90 \%$ dengan taraf keberhasilan sangat baik. Persentase ini mencapai 85,5\%, sudah memenuhi taraf keberhasilan yang ditetapkan oleh peneliti yaitu $\geq 80 \%$. Hal ini dapat disimpulkan bahwa pembelajaran dari segi guru telah berhasil, baik pada siklus I maupun siklus II.

Berdasarkan Tabel 2 dapat diketahui bahwa kegiatan siswa pada siklus I pertemuan pertama mencapai $62 \%$ dengan taraf keberhasilan baik, sedangkan pada pertemuan kedua mengalami peningkatan mencapai $66,5 \%$ dengan taraf keberhasilan baik. Persentase ini mencapai $64,5 \%$ belum memenuhi taraf keberhasilan yang ditetapkan peneliti yaitu $\geq 80 \%$ sehingga peneliti melanjutkan ke siklus berikutnya untuk melihat peningkatan kegiatan siswa dalam pembelajaran. Pada siklus II persentase keberhasilan meningkat, pertemuan pertama mencapai $77,125 \%$ dengan taraf keberhasilan baik, sedangkan pertemuan kedua 86,375\% dengan taraf keberhasilan sangat baik. Persentase ini mencapai $81,755 \%$ sudah memenuhi taraf keberhasilan tindakan yang ditetapkan peneliti yaitu $\geq 80 \%$. Jadi dapat disimpulkan bahwa pembelajaran dari segi siswa telah berhasil.

Berdasarkan Tabel 3 di atas dapat diketahui bahwa hasil tes akhir pada siklus I mencapai $21,43 \%$ dari 42 siswa yang mengikuti tes dan siswa yang tuntas 9 siswa dengan keterangan tidak tuntas pada siklus I. Persentase ini belum memenuhi taraf keberhasilan yang ditetapkan, yaitu $\geq 75 \%$ siswa mendapat nilai $\geq 70$ sehingga Peneliti merencanakan siklus berikutnya. Sedangkan pada siklus II persentase ini meningkat menjadi 78,57\% dari 42 siswa yang mengikuti tes dan siswa yang tuntas ada 33 siswa dengan keterangan tuntas dalam siklus II. Persentase ini sudah mencapai taraf keberhasilan yang telah ditetapkan, yaitu $75 \%$ siswa mendapat nilai $\geq 70$ sehingga siklus dapat dihentikan. Dari hasil analisis data kualitatif dan 
kuantitatif di atas dapat diketahui bahwa pembelajaran baik dari segi guru maupun siswa telah mengalami peningkatan dan sesuai dengan standar keberhasilan yang telah ditetapkan.

\section{SIMPULAN DAN SARAN}

Dari analisis data dan pembahasan yang telah diuraikan, secara umum dapat disimpulkan bahwa penerapan strategi pembelajaran time token student facilitator and explaining dapat meningkatkan kemampuan berpikir kreatif siswa kelas VIII MTs. Al- Ittihad Belung Poncokusumo Malang tahun ajaran 2016/2017. Secara khusus simpulan penelitian ini dapat dikelompokan dari sisi proses dan sisi hasil.

Berdasarkan paparan data dan pembahasan, peneliti menyarankan kepada berbagai pihak, sebagai berikut. (1) bagi lembaga yang bersangkutan disarankan agar dapat membuat dan merumuskan kebijakan atau kurikulum yang tepat dan sesuai dengan kepribadian serta kecerdasan yang dimiliki oleh siswa; (2) bagi guru matematika strategi pembelajaran time token student facilitator and explaining disarankan agar dapat dijadikan sebagai salah satu alternatif pembelajaran yang dapat digunakan untuk meningkatkan kemampuan berpikir kreatif siswa; dan (3) bagi peneliti selanjutnya disarankan agar dapat mengembangkan penelitian penerapan strategi time token student facilitator and explaining pada materi yang lainnya.

\section{UCAPAN TERIMA KASIH}

Ucapan terima kasih saya sampaikan kepada rektor Universitas Islam Malang, Dekan FKIP Universitas Islam Malang, Dosen Pembimbing Skripsi, pengelola JPM (Jurnal Pendidikan matematka), dan kedua orang tua, saudara, sahabat, dan teman-teman jurusan pendidikan matematika, serta pihak-pihak yang ikut serta membantu penyusunan artikel ini.

\section{DAFTAR RUJUKAN}

Arikunto, S. (2013). Prosedur Penelitian: Suatu Pendekatan Praktek. Jakarta: PT Rineka Cipta.

Darmansyah. (2010). Strategi Pembelajaran Menyenangkan Dengan Humor. PT Bumi Aksara

Filsaime, D. K. (2008). Menguak Rahasia Berpikir Kritis Dan Kreatif. Jakarta: Prestasi Pustakarya.

Moleong, L. J. (2013). Metodologi Penelitian Kualitatif. Bandung: PT Remaja Rosdakarya.

Sugiyono. (2015). Metode Penelitian Pendidikan Pendekatan Kuantitatif, Kualitatif, dan $R \& D$. Bandung: Alfabeta.

Sundayana, R. (2015). Media dan Alat Peraga dalam Pembelajaran Matematika. Bandung: Alfabeta, CV.

Wiraatmadja, R. (2012). Metode Penelitian Tindakan Kelas. Bandung: PT Remaja Rosdakarya. 